University of Nebraska - Lincoln

DigitalCommons@University of Nebraska - Lincoln

BIOMASS AND NITROGEN TRAITS OF SUMMER PIGEON PEAS AND WINTER WHEAT GROWN FOR THREE ROTATIONS IN CONTAINERS

\author{
Srinivas C. Rao \\ USDA-ARS \\ Charles T. MacKown \\ USDA-ARS \\ James E. Bidlack \\ University of Central Oklahoma, jbidlack@ucok.edu
}

Follow this and additional works at: https://digitalcommons.unl.edu/usdaarsfacpub

Part of the Agricultural Science Commons

\footnotetext{
Rao, Srinivas C.; MacKown, Charles T.; and Bidlack, James E., "BIOMASS AND NITROGEN TRAITS OF SUMMER PIGEON PEAS AND WINTER WHEAT GROWN FOR THREE ROTATIONS IN CONTAINERS" (2002). Publications from USDA-ARS / UNL Faculty. 581.

https://digitalcommons.unl.edu/usdaarsfacpub/581
}

This Article is brought to you for free and open access by the U.S. Department of Agriculture: Agricultural Research Service, Lincoln, Nebraska at DigitalCommons@University of Nebraska - Lincoln. It has been accepted for inclusion in Publications from USDA-ARS / UNL Faculty by an authorized administrator of DigitalCommons@University of Nebraska - Lincoln. 


\title{
BIOMASS AND NITROGEN TRAITS OF SUMMER PIGEON PEAS AND WINTER WHEAT GROWN FOR THREE ROTATIONS IN CONTAINERS
}

\author{
Srinivas C. Rao, ${ }^{1}$ Charles T. MacKown, ${ }^{1}$ and \\ James E. Bidlack ${ }^{2, *}$ \\ ${ }^{1}$ USDA-ARS Grazinglands Research Laboratory, 7207 \\ W. Cheyenne St., El Reno, OK 73036 \\ ${ }^{2}$ Department of Biology, University of Central Oklahoma, \\ Edmond, OK 73034
}

\begin{abstract}
Pigeon pea [Cajanus cajan (L.) Millsp.] cultivars, 'Georgia-1' and 'ICPL-87', were grown without inoculation and with Bradyrhizobium inoculation (multistrain, TAL 1127, or TAL 1132) to evaluate legume dry weight (DW) and nitrogen (N) content, soil mineral N, and subsequent wheat (Triticum aestivum L.) productivity. Pigeon peas were grown during summer and 'TAM 101' wheat was grown during winter, along with summer fallow controls fertilized with 0,45 , and $90 \mathrm{~kg} \mathrm{Nha}^{-1}$, in $36-\mathrm{cm}$ diam. 20-L pots from 1992 to 1995 . Representative pigeon peas were harvested in the fall and remaining plants were incorporated into the soil. Wheat was planted and soil cores were collected at 35 to $48 \mathrm{~d}$ after pigeon pea harvest. Wheat was harvested the following spring. Factors affecting DW and $\mathrm{N}$ content of both
\end{abstract}

*Corresponding author. E-mail: jbidlack@ucok.edu

897 
crops included length of growing season, environmental variation, and contribution of residual N. Among pigeon pea cultivars, Georgia-1 occasionally demonstrated higher DW and $\mathrm{N}$ content compared with ICPL-87. Estimation of $\mathrm{N}$ provided by pigeon pea to the last wheat crop in the third sequence of yearly rotations was $30 \mathrm{~kg} \mathrm{Nha}^{-1}$. Pigeon pea treatments demonstrating highest DW, $\mathrm{N}$ content, and contribution to soil $\mathrm{N}$ generally produced winter wheat with higher yield and $\mathrm{N}$ content compared with other treatments. While yield and $\mathrm{N}$ content of winter wheat fertilized at $90 \mathrm{~kg} \mathrm{Nha}^{-1}$ either decreased or stayed the same from 1993 to 1995 , these same measurements in wheat following pigeon peas demonstrated a 3- to 4-fold increase over the same time period and warrant further research in field rotation systems of the southern Great Plains.

\section{INTRODUCTION}

Pigeon pea [Cajanus cajan (L.) Millsp.] can persist during hot and dry periods (1) such as those encountered after winter wheat (Triticum aestivum L.) harvest in the southern Great Plains. Therefore, pigeon pea has been promoted as a crop that can provide additional grain (2) and forage (3) during summer months in stress prone environments. Pigeon pea can also help minimize soil erosion, suppress weed proliferation during summer months (4), and fix atmospheric $\mathrm{N}_{2}$ for use by subsequent crops (5). However, the full potential for seasonal forage production, $\mathrm{N}$-fixation, and subsequent benefit to winter wheat in the southern Great Plains is unknown.

In India, pigeon pea has been reported to fix 58 to $88 \mathrm{~kg} \mathrm{~N} \mathrm{ha}^{-1}$ in sole crop systems (6) and may provide 30 to $50 \mathrm{~kg} \mathrm{Nha}^{-1}$ of residual $\mathrm{N}$ in crop rotations with maize [Zea mays (L.)] (7), sorghum [Sorghum bicolor (L.) Moench], or wheat (5). It is not known whether similar $\mathrm{N}$ returns are possible in cropping systems of the U.S. southern Great Plains.

In other parts of the world, research has shown that the use of specific cultivars and (Brady)Rhizobium strains may optimize yield $(8,9)$ and $\mathrm{N}_{2}$-fixation $(10,11)$ of pigeon pea. One of the first steps in evaluating the benefits of pigeon pea, therefore, is to determine whether or not similar variation exists in the performance of cultivars and inoculum strains fit for this region. In this investigation, pigeon peas were grown in the summer, followed by winter wheat, to simulate a pigeon pea-wheat cropping system in Oklahoma. Cultivar and inoculum strain combinations were evaluated to determine the effect(s) of environment (as influenced by year to year variation), cultivar, Bradyrhizobium strain, and interactions thereof, on biomass components and $\mathrm{N}$ content of pigeon 
pea, as well as available soil mineral $\mathrm{N}$ after harvest. Biomass and $\mathrm{N}$ accumulation of winter wheat were measured to assess potential benefits of a pigeon pea rotation.

\section{MATERIALS AND METHODS}

Experiments were conducted from 1992 to 1995 outside at the University of Central Oklahoma in Edmond, Oklahoma. Pigeon peas were grown during summer and harvested in late summer or early fall of 1992, 1993, and 1994. Winter wheat was planted following pigeon peas and harvested in spring of 1993, 1994, and 1995. All plants were grown in 36-cm diam. clay pots with free drainage. The pots contained about $20 \mathrm{~L}$ of a 1:1 mixture of potting soil [Fafard Soil Mix No. 2, Fafard Soil Company, Quebec, Canada (12)] and Dale silt loam (fine-silty, mixed, thermic Pachic Haplustoll) with a pH of 6.6. About $3 \mathrm{~L}$ of the same soil mix was added to each pot after wheat harvest to compensate for losses from samples of soil and legume roots taken during the previous year.

An early-maturing pigeon pea cultivar, 'ICPL-87,' and a mid-maturing pigeon pea cultivar, 'Georgia-1,' were obtained from the International Crop Research Institute for Semi-Arid Tropics at Patancheru, India, and the Horticulture Department at the University of Georgia, Tifton, GA, respectively. 'TAM 101' winter wheat was obtained from a local seed distributor in El Reno, OK.

Two distinct strains of pigeon pea Bradyrhizobium, TAL 1127 (IHP 38) and TAL 1132 (IHP 195), recommended by the Nitrogen Fixation by Tropical Agricultural Legumes Project, University of Hawaii, Paia, HI, were used. In addition, a commercial multistrain inoculum (Nitragen; LiphaTech, Inc., Milwaukee, WI) and a control treatment without inoculum were used. Seed was inoculated by mixing peat inoculum $\left(10 \mathrm{mg} \mathrm{seed}^{-1} ; 10^{9}\right.$ cells $^{-1}$ peat $)$ with legume seeds coated with molasses. Seeds treated with only molasses served as controls.

A total of eight treatment combinations, consisting of two cultivars and four inoculum treatments of each cultivar, were evaluated for the summer legume part of this experiment. Three additional pots per replicate were used as fallow treatments of the winter wheat part of the experiment and received 0,45 , or $90 \mathrm{~kg}$ $\mathrm{Nha}^{-1}$ as urea each year about $4 \mathrm{wk}$ after planting the wheat. All pots were arranged in a randomized complete block design with four replications.

Exactly 10 inoculated or uninoculated pigeon pea seeds were planted per legume pot on 30 July 1992, 11 July 1993, and 16 June 1994. Soil was fertilized each year with $40 \mathrm{~kg} \mathrm{Pha}^{-1}$ as treble superphosphate. Plants were watered at least every $2 \mathrm{~d}$ throughout the growing season. Temperature and rainfall records were obtained from an Oklahoma Climatological Station 


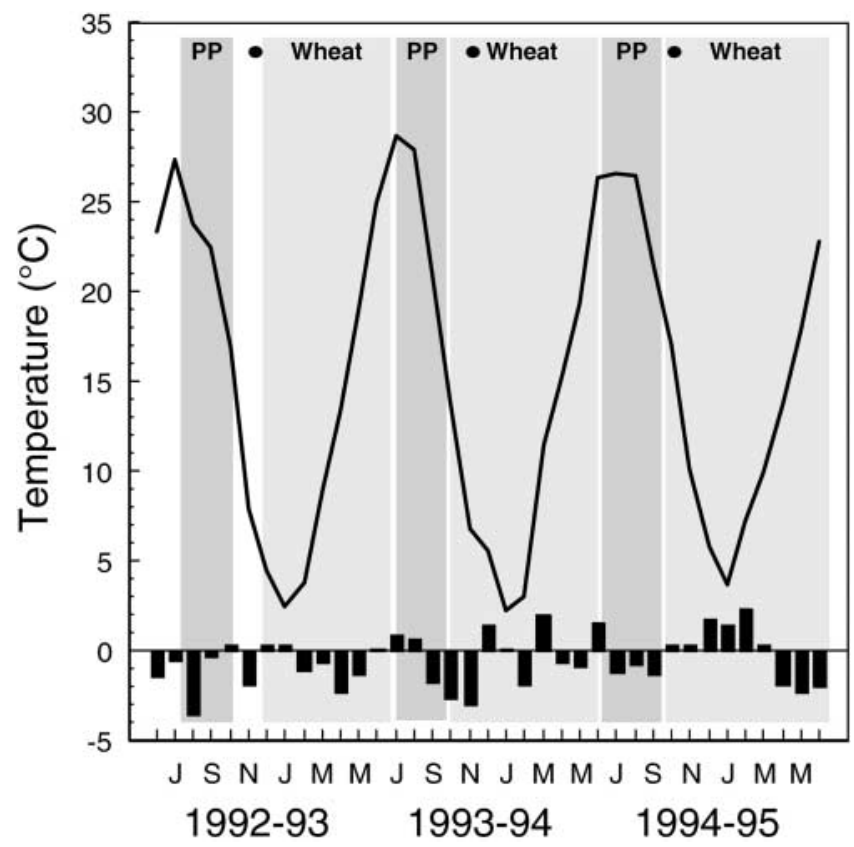

Figure 1. Average monthly temperatures (solid line) and departures from the normal (vertical solid bars) for the Oklahoma City weather station located $37 \mathrm{~km}$ from the experimental site. Vertical shaded bars represent growth duration of the pigeon pea (PP) and winter wheat (Wheat) crop rotations, and filled circles indicate sampling dates for soil cores.

located $37 \mathrm{~km}$ away (Fig. 1). Seedlings were thinned to five plants per pot within $2 \mathrm{wk}$ of emergence. One pigeon pea plant (roots and shoots) was removed on three successive dates, the last of which was used to collect data for this investigation. Because year-to-year variation affected time of planting and harvest, the ages of pigeon peas used for analyses were 84 (22 October 1992), 88 (7 October 1993), and 98 (22 September 1994) d after planting (DAP). Whole plants were removed by excavating roots and soil in a $10-\mathrm{cm}$ core centered on the stem to the complete depth of the pot. Leaves, stems, and pods were separated from shoots and dried for $96 \mathrm{~h}$ at $40^{\circ} \mathrm{C}$ to obtain dry weight (DW) and to prepare tissues for $\mathrm{N}$ determinations.

After harvest, existing pods were removed from the remaining two plants and above ground vegetative growth was chopped and incorporated into the top $10 \mathrm{~cm}$ of soil. Approximately 50 wheat seeds were then planted into each pot on 12 December 1992, 12 October 1993, and 1 October 1994. All pots were watered to ensure hydration of seeds and incorporation of fertilizer in appropriate treatments. All treatments were thinned to 25 wheat seedlings per pot after germination. 
Two soil cores (2.5-cm diam., 30-cm deep) were collected from each pot within 4 wk after wheat planting, which was at 39, 48, and $35 \mathrm{~d}$ after harvesting pigeon peas in 1992, 1993, and 1994, respectively. Wheat plants were thereafter watered as needed until harvest at 210 (4 July 1993), 229 (7 June 1994), and 255 (22 June 1995) DAP. Wheat plants were cut at $5.0 \mathrm{~cm}$ above soil surface and the stubble was incorporated into the soil with a hand trowel to a depth of $10 \mathrm{~cm}$ before planting legume seed.

Dried plant parts, ground to pass through a 1-mm screen of an Udy Cyclone Mill (Udy, Ft. Collins, CO), and composite soil core samples from each pot were used for $\mathrm{N}$ analyses. Total $\mathrm{N}$ concentration of plant tissue was determined by combustion analysis using a CHN-1000 analyzer (LECO Co., St. Joseph, MO). Soil samples were frozen immediately at $-15^{\circ} \mathrm{C}$ and within $3 \mathrm{wk}$ analyzed for mineral $\mathrm{N}$ after thawing at $23^{\circ} \mathrm{C}$ and extracting the thawed samples within $2 \mathrm{~h}$ using $2 \mathrm{M} \mathrm{KCl}$. Micro-Kjeldahl steam distillation was used to determine $\mathrm{NH}_{4}^{+}-\mathrm{N}$ and $\mathrm{NO}_{3}^{-}-\mathrm{N}(13)$.

Analyses of variance (ANOVA) were used to determine differences in traits as affected by year, cultivar, inoculum, and interactions thereof, as well as fallow treatments. Statistical analyses were conducted separately for pigeon pea and wheat data because the wheat experiment included analyses of additional treatments following a summer fallow period. In both cases, SAS PROC GLM (14) was used to process data sets containing missing values. When year effects were significant, the effects of treatments on traits were evaluated for each year. Least significant differences were evaluated at the 0.05 level of probability.

\section{RESULTS}

Pigeon pea DW components and $\mathrm{N}$ content were significantly affected by year (Table 1). Cultivar significantly affected stem and total DW as well as stem $\mathrm{N}$ content, and the year $\times$ cultivar interaction reflected significant variation in stem DW and N. Inoculum and inoculum interaction effects for all biomass and $\mathrm{N}$ content traits were not significant. Because ANOVAs revealed significant variation in DW and $\mathrm{N}$ contents of several plant parts as affected by year and cultivar, tables were constructed to evaluate differences between cultivars for each year.

Pigeon pea plants were harvested at 84, 88, and 98 DAP in 1992, 1993, and 1994, respectively. Dry weight components increased each year (Table 2); the increase from 1992 to 1993 was 2.7-fold and from 1993 to 1994, the increase was 2.9-fold. The contribution of leaf DW to total shoot DW was $47 \%$ in 1992, but as total shoot DW increased in 1993 and 1994, the contribution of leaf DW to total shoot DW decreased to about $40 \%$. Pod DW was determined for both cultivars in 1994 but not in 1992 or 1993 because few, if any, pods were formed on the first two legume crops. In 1994, pod DW was not significantly different between 


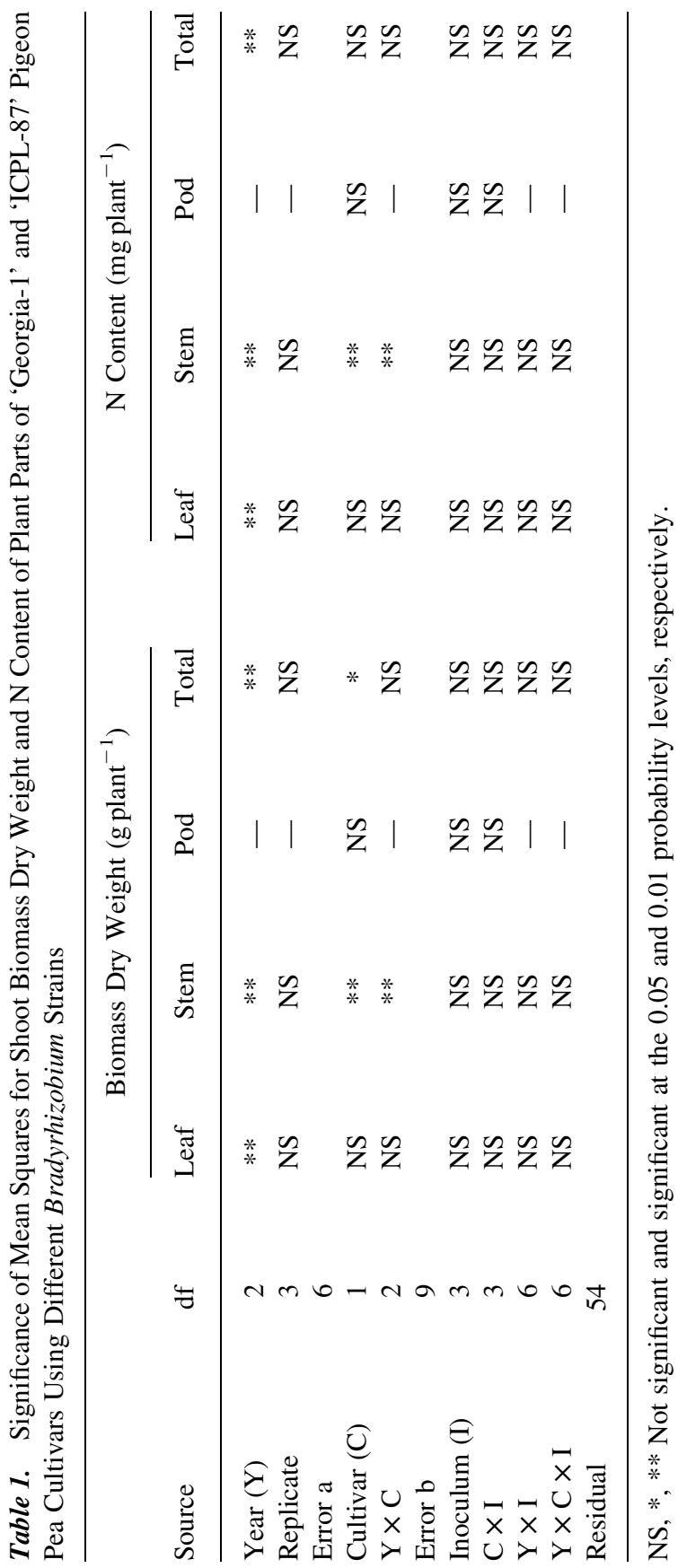


Table 2. Biomass Dry Weights of 'Georgia-1' and 'ICPL-87' Pigeon Pea Cultivars Harvested at 84, 88, and $98 \mathrm{~d}$ After Planting in 1992, 1993, and 1994, Respectively

\begin{tabular}{|c|c|c|c|c|}
\hline Cultivar & $\begin{array}{c}\text { Leaf } \\
\left(\text { g plant }^{-1}\right)\end{array}$ & $\begin{array}{c}\text { Stem } \\
\left(\mathrm{g} \mathrm{plant}^{-1}\right)\end{array}$ & $\begin{array}{c}\text { Pod } \\
\left.\text { (g plant }^{-1}\right)\end{array}$ & $\begin{array}{c}\text { Total } \\
\left.\text { (g plant }^{-1}\right)\end{array}$ \\
\hline \multicolumn{5}{|l|}{$1992^{\mathrm{a}}$} \\
\hline Georgia-1 & 2.26 & 2.52 & - & 4.78 \\
\hline ICPL-87 & 2.19 & 2.42 & - & 4.61 \\
\hline Mean & 2.22 & 2.47 & - & 4.69 \\
\hline LSD (0.05) & NS & NS & - & NS \\
\hline \multicolumn{5}{|l|}{1993} \\
\hline Georgia-1 & 5.71 & 7.85 & - & 13.6 \\
\hline ICPL-87 & 4.59 & 6.77 & - & 11.4 \\
\hline Mean & 5.15 & 7.31 & - & 12.5 \\
\hline $\operatorname{LSD}(0.05)$ & NS & NS & - & NS \\
\hline \multicolumn{5}{|l|}{1994} \\
\hline Georgia-1 & 14.9 & 23.5 & 3.40 & 41.8 \\
\hline ICPL-87 & 12.8 & 15.9 & 1.96 & 30.7 \\
\hline Mean & 13.9 & 19.7 & 2.73 & 36.3 \\
\hline $\operatorname{LSD}(0.05)$ & NS & 6.7 & NS & NS \\
\hline \multicolumn{5}{|c|}{ All years combined } \\
\hline Georgia-1 & 7.62 & 11.3 & - & 18.9 \\
\hline ICPL-87 & 6.53 & 8.36 & - & 14.8 \\
\hline Mean & 7.08 & 9.83 & - & 16.9 \\
\hline $\operatorname{LSD}(0.05)$ & NS & 1.89 & - & 3.5 \\
\hline
\end{tabular}

NS Not significant at the 0.05 probability level.

${ }^{a}$ Least significant differences across years are 2.57, 2.91, and 6.17 for leaf, stem, and total shoot dry weight, respectively.

pigeon pea cultivars and contributed $7.2 \%$ of the total shoot DW. Dry weight values were always numerically greater for Georgia-1 compared with ICPL-87, but cultivar differences in dry weight were seldom significant. Georgia-1 stem DW was greater than that of ICPL-87 in 1994 and averaged across years. Total DW of Georgia-1 was also greater than ICPL-87 when averaged across years.

Nitrogen content of plant parts increased each year (Table 3), 3.2-fold from 1992 to 1993 and 2.5-fold from 1993 to 1994 . Leaf $\mathrm{N}$ content was greater than stem $\mathrm{N}$ content because leaf $\mathrm{N}$ concentration $\left(26.7\right.$ to $33.8 \mathrm{mg} \mathrm{g}^{-1}$; data not shown) was more than stem $\mathrm{N}$ concentration (6.6 to $13.6 \mathrm{mg} \mathrm{g}^{-1}$; data not shown) throughout the experiment. Even though the $\mathrm{N}$ concentrations of pods (26.4 to $27.5 \mathrm{mg} \mathrm{g}^{-1}$; data not shown) in 1994 was equal or slightly less than that of leaves, the amount of $\mathrm{N}$ contributed by pods was less than that of leaves or stems 
Table 3. Amount of N in 'Georgia-1' and 'ICPL-87' Pigeon Pea Cultivars Harvested at 84, 88, and 98 d After Planting in 1992, 1993, and 1994, Respectively

\begin{tabular}{|c|c|c|c|c|}
\hline Cultivar & $\begin{array}{c}\text { Leaf } \\
\left(\mathrm{mg} \mathrm{plant}^{-1}\right)\end{array}$ & $\begin{array}{c}\text { Stem } \\
\left(\mathrm{mg} \mathrm{plant}^{-1}\right)\end{array}$ & $\begin{array}{c}\text { Pod } \\
\left(\mathrm{mg} \mathrm{plant}^{-1}\right)\end{array}$ & $\begin{array}{c}\text { Total } \\
\left(\mathrm{mg} \mathrm{plant}^{-1}\right)\end{array}$ \\
\hline \multicolumn{5}{|l|}{$1992^{\mathrm{a}}$} \\
\hline Georgia-1 & 62.7 & 25.6 & - & 88.3 \\
\hline ICPL-87 & 58.4 & 23.0 & - & 81.4 \\
\hline Mean & 60.6 & 24.3 & - & 84.9 \\
\hline LSD(0.05) & NS & NS & - & NS \\
\hline \multicolumn{5}{|l|}{1993} \\
\hline Georgia-1 & 184 & 109 & - & 293 \\
\hline ICPL-87 & 155 & 90.7 & - & 246 \\
\hline Mean & 170 & 99.7 & - & 270 \\
\hline $\operatorname{LSD}(0.05)$ & NS & NS & - & NS \\
\hline \multicolumn{5}{|l|}{1994} \\
\hline Georgia-1 & 467 & 163 & 95.0 & 725 \\
\hline ICPL-87 & 432 & 106 & 53.1 & 591 \\
\hline Mean & 449 & 134 & 75.6 & 659 \\
\hline $\operatorname{LSD}(0.05)$ & NS & NS & NS & NS \\
\hline \multicolumn{5}{|c|}{ All years combined } \\
\hline Georgia-1 & 238 & 99.1 & - & 369 \\
\hline ICPL-87 & 215 & 73.2 & - & 306 \\
\hline Mean & 227 & 86.2 & - & 338 \\
\hline $\operatorname{LSD}(0.05)$ & NS & 19.4 & - & NS \\
\hline
\end{tabular}

NS Not significant at the 0.05 probability level.

${ }^{a}$ Least significant differences across years are 87.1, 45.5, and 142 for leaf, stem, and total shoot $\mathrm{N}$, respectively.

because of low pod weights (Table 2). The amounts of $\mathrm{N}$ in Georgia-1 plant parts were always numerically greater than that of ICPL-87, but were significant only in stems when averaged across years.

Year, treatment, and the year $\times$ treatment interaction effects were significant for soil mineral $\mathrm{N}$ as well as winter wheat yield and $\mathrm{N}$ content (Table 4). Most of the year-to-year differences for these traits could be attributed to differences between summer legume and summer fallow rotations. In 1992, soil mineral $\mathrm{N}$ was unaffected by treatment and averaged only $3.88 \mathrm{mg} \mathrm{kg}^{-1}$ (Table 5). As in 1992, differences in soil mineral $\mathrm{N}$ among the summer fallow treatments were not significant in 1993 and 1994. The concentration of soil mineral $\mathrm{N}$ in the fallow treatments, however, was less than some of the pigeon pea treatments, particularly those that were inoculated with TAL 1127 and TAL 1132 Bradyrhizobium strains. 


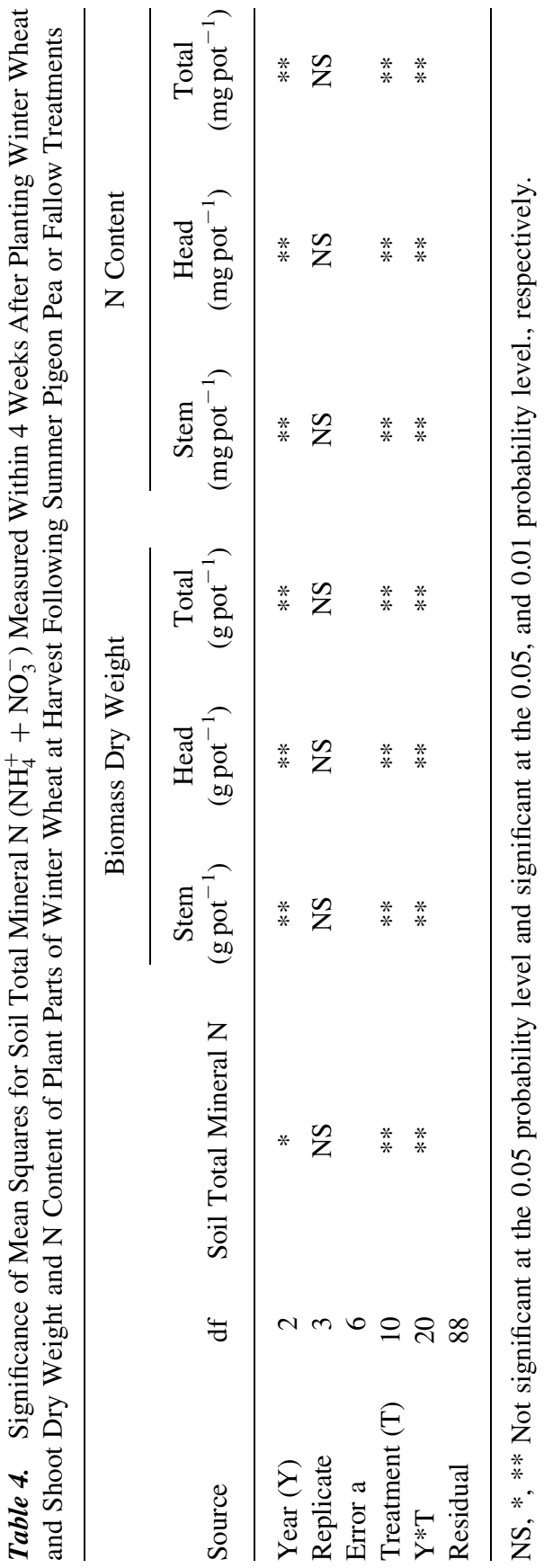


Table 5. Soil Total Mineral $\mathrm{N}\left(\mathrm{NH}_{4}^{+}+\mathrm{NO}_{3}^{-}\right)$Measured Within 4 Weeks After Planting Winter Wheat and Before Additions of Fertilizer N to Fallow Treatments (Shoot Residues of Legumes Were Incorporated in the Top $10 \mathrm{~cm}$ of Soil 39, 48, and $35 \mathrm{~d}$ Before Collecting Soil Samples in 1992, 1993, and 1994, Respectively)

\begin{tabular}{lccc}
\hline & \multicolumn{3}{l}{ Soil Total Mineral N $\left[\mathrm{mg}\left(\mathrm{NH}_{4}^{+}+\mathrm{NO}_{3}^{-}\right)-\mathrm{N} \mathrm{kg}^{-1}\right]$} \\
\cline { 2 - 4 } Treatment & 1992 & 1993 & 1994 \\
\hline Wheat after Georgia-1 & & & \\
$\quad$ Control & 3.58 & 5.33 & 12.3 \\
Multistrain & 2.92 & 5.11 & 14.6 \\
TAL 1127 & 3.90 & 7.43 & 21.3 \\
TAL 1132 & 4.17 & 7.69 & 18.4 \\
Wheat after ICPL-87 & & & \\
Control & 4.16 & 5.10 & 14.2 \\
Multistrain & 4.41 & 4.54 & 16.9 \\
TAL 1127 & 4.20 & 7.05 & 16.3 \\
TAL 1132 & 4.63 & 6.93 & \\
Wheat after fallow & & & 9.93 \\
0 kg N ha & & & \\
$45 \mathrm{~kg} \mathrm{Nha}^{-1}$ & 3.76 & 2.80 & 8.44 \\
$90 \mathrm{~kg} \mathrm{Nha}^{-1}$ & 3.80 & 3.97 & 4.96 \\
LSD (0.05) & 3.18 & 2.81 & \\
\hline
\end{tabular}

After the first year, biomass and $\mathrm{N}$ content traits of the legume-wheat rotation were usually greater than even the fallow treatment fertilized with $90 \mathrm{~kg} \mathrm{Nha}^{-1}$ (Tables 6 and 7). Productivity differences between legume and fallow rotations were greatest for the third cycle. Shoot biomass and $\mathrm{N}$ content of wheat grown after legumes increased 3.4-fold from 1993 to 1995. In contrast, from 1993 to 1995 shoot biomass decreased 2.9-fold and shoot $\mathrm{N}$ content decreased 1.7-fold in fallow-wheat rotation treatments. For the first cycle of rotations in 1993, total shoot biomass of wheat grown after summer fallow and fertilized with $90 \mathrm{~kg} \mathrm{~N} \mathrm{ha}^{-1}$ was greater than all other treatments except Georgia-1 inoculated with TAL 1127 and TAL 1132 (Table 6). Differences in total shoot $\mathrm{N}$ accumulation among treatments, however, were not significant the first year (Table 7). In 1994 and 1995, differences in biomass and $\mathrm{N}$ content traits of wheat among the legume-inoculum treatment combinations were almost always not significant, but biomass and $\mathrm{N}$ content traits of wheat plants grown after legumes were almost always greater than those of the summer fallow treatments. During the last of the three cycles (1995), wheat plants of the $0 \mathrm{~kg} \mathrm{~N} \mathrm{ha}^{-1}$ fallow treatment emerged but within the first $6 \mathrm{wk}$ they were chlorotic and stunted and eventually died following a series of hard freezes that occurred 8 wk after 


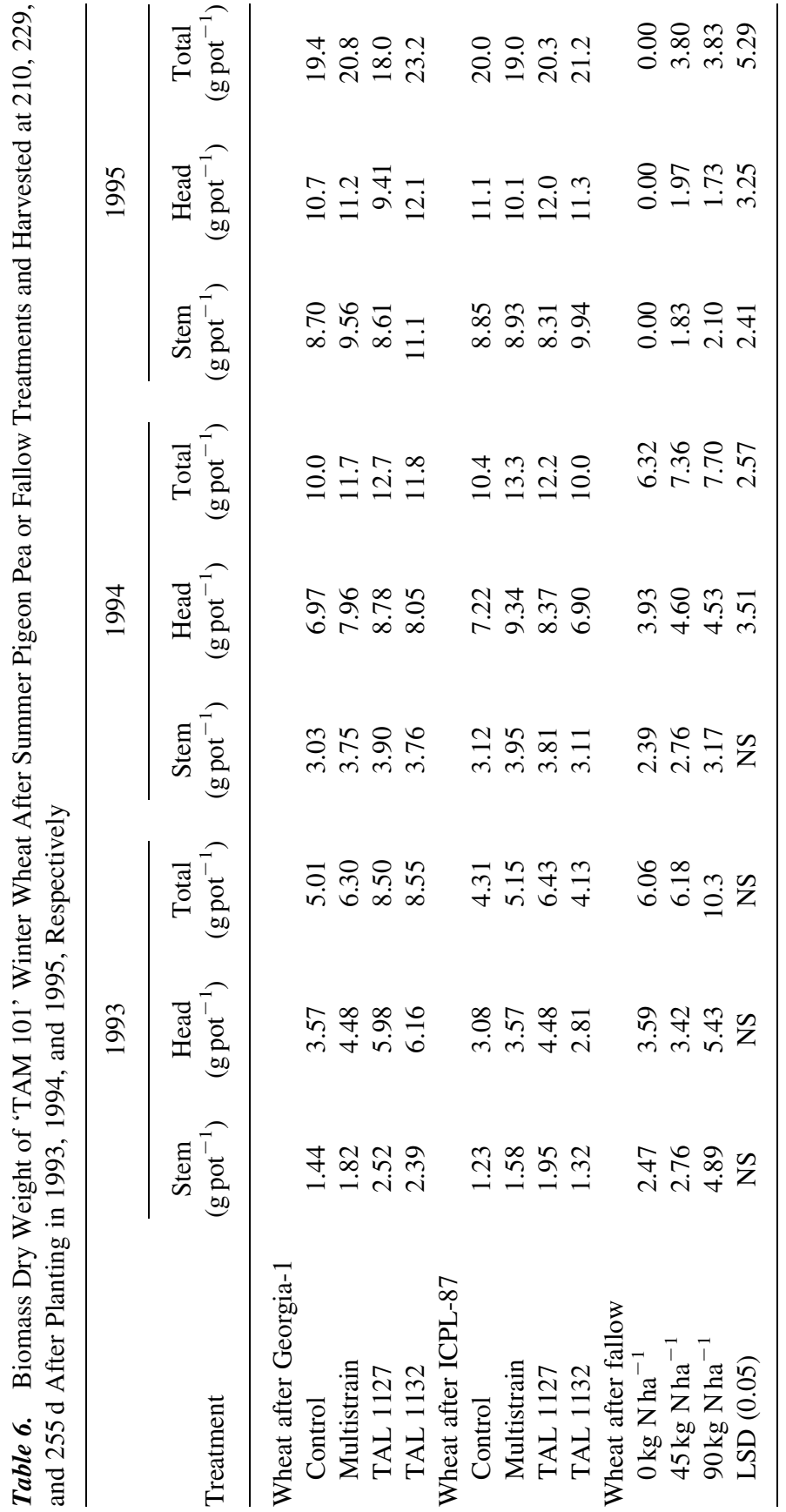




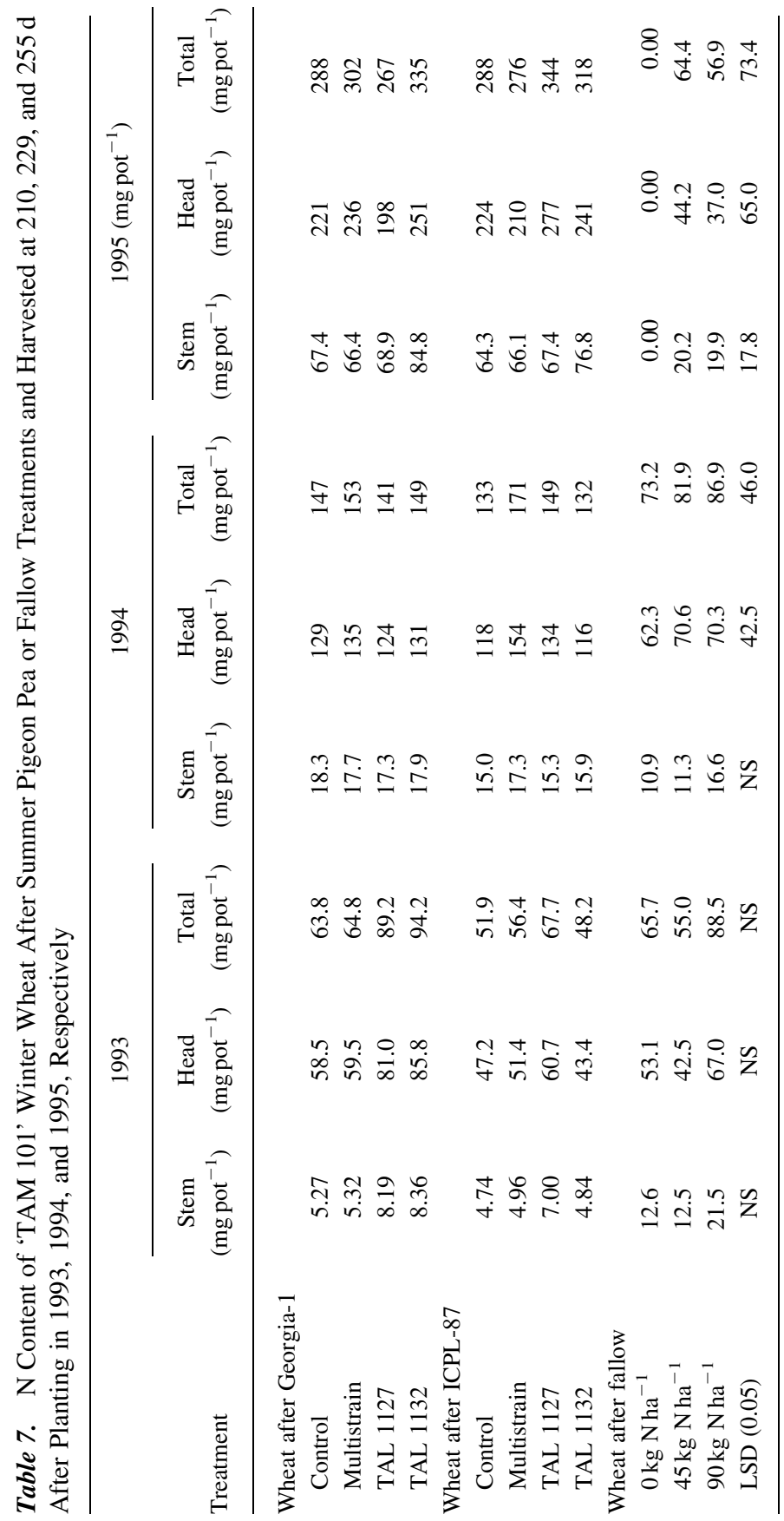


planting. During this cycle, wheat after fallow that was fertilized with 45 or $90 \mathrm{~kg}$ $\mathrm{Nha}^{-1}$ survived but showed signs of $\mathrm{N}$ stress and was less tolerant of the cold weather than wheat grown after the legumes. Within each year, treatment effects on biomass and $\mathrm{N}$ content of wheat stem and head parts followed the same trends as the total shoot biomass and $\mathrm{N}$ traits.

\section{DISCUSSION}

Pigeon pea productivity failed to respond to inoculation. Both shoot biomass and $\mathrm{N}$ content of uninoculated plants were equivalent to those inoculated with a multistrain mixture or TAL1127 and TAL 1132 pigeon pea specific Bradyrhizobium. These results are consistent with a nearly complete lack of significant inoculum effects on nodule number, mass, and nitrogenase activity throughout growth as was previously reported (15).

Productivity and $\mathrm{N}$ accumulation of both cultivars increased $(P \leq 0.05)$ each year. The yearly increases were partially the consequence of differences in growing degree days (GDD) among years. Duration of crop growth increased from 84 to 88 to $98 \mathrm{~d}$ between 1992 and 1994, and the corresponding GDD increased from 748 to 1098 to1280. Accumulated GDD in 1992 was $15 \%$ less than normal, while in 1993 and 1994, accumulated GDD was no more than $4 \%$ less than normal and is reflected by average monthly temperature deviations from normals during the pigeon pea growth intervals (Figure 1). Averaged over all years, total biomass of Georgia-1 pigeon pea was $27 \%$ greater than ICPL-87, primarily due to the greater stem biomass of Georgia-1 (Table 2). It is generally accepted in this study and others (16) that the yield and nitrogen fixing capacity of pigeon pea are affected by climate, length of season, and duration of the cultivar $(10,17)$.

At the end of each pigeon pea growth interval, the leaf and stem tissues of two plants (equivalent to 196,000 plants $\mathrm{ha}^{-1}$ ) were returned to the soil to provide $\mathrm{N}$ for the following winter wheat. The average amount of $\mathrm{N}$ incorporated was about 17, 53, and $114 \mathrm{~kg} \mathrm{ha}^{-1}$, in 1992, 1993, and 1994, respectively. These amounts, particularly in 1992 and 1993, are less than one would anticipate for a field grown crop. Typically, 'Georgia-2' pigeon pea, a slightly earlier maturing cultivar than Georgia-1, when grown at our location produces leaf plus stem tissue with about $188 \mathrm{~kg} \mathrm{Nha}^{-1}$ at 85 DAP and a density of 111,000 plants ha $^{-1}$ (Rao, personal communication, 1999). Measurements of total soil mineral $\mathrm{N}$ at 5 to $7 \mathrm{wk}$ after harvesting the legumes followed the same trend as yearly legume $\mathrm{N}$ content. Hence, total soil mineral $\mathrm{N}$ increased each year from 3.9 to 6.1 to $14.0 \mathrm{mg} \mathrm{kg}^{-1}$ between 1992 and 1994 (Table 5, average of legume treatments each year). Because the amount of $\mathrm{N}$ returned by the legumes in 1992 was negligible, the mineral $\mathrm{N}$ levels were similar for both summer legume and fallow treatments. As the incorporation of legume N increased in 1993 and 1994, 
mineralization of legume tissues often led to an increase in mineral $\mathrm{N}$ compared to fallow treatments (Table 5).

Recent studies (18) demonstrate that wheat yield can vary as a result of rotation with grain legumes having different $\mathrm{N}_{2}$ fixing capacities. Incorporation of the first crop of summer legumes into the soil elicited neither a beneficial nor a harmful response for the growth and $\mathrm{N}$ accumulation of the following winter wheat crop. For the first wheat crop, nearly all pigeon pea and inoculum combinations gave wheat total biomass yields equivalent to fallow rotation fertilized with $45 \mathrm{~kg}$ $\mathrm{Nha}^{-1}$ (Table 5), while differences in wheat total $\mathrm{N}$ accumulation were not significant among legume and fallow treatment combinations (Table 6). A clear benefit of legumes to wheat, however, was evident for the last two cycles of the rotation. Both an increase in legume productivity (and $\mathrm{N}$ accumulation) and a decrease in wheat productivity in the fallow rotation account for the legume rotation benefits of wheat harvested in 1994 and 1995.

Inputs of $\mathrm{N}$, whether derived from fertilizer or legumes, were always substantially greater than the $\mathrm{N}$ recovered by winter wheat. Conversion of $\mathrm{mg}$ $\mathrm{N} \mathrm{pot}^{-1}$ accumulated by wheat following pigeon peas (Table 7) revealed averages of $6.6,14$, and $30 \mathrm{~kg} \mathrm{Nha}^{-1}$ in 1993,1994 , and 1995 , respectively, even though $\mathrm{N}$ added by legumes averaged 17,53 , and $114 \mathrm{~kg} \mathrm{Nha}^{-1}$. This same conversion for fertilizer $\mathrm{N}$ revealed only $8.7,8.5$, and $5.6 \mathrm{~kg} \mathrm{Nha}^{-1}$ was accumulated by wheat following application of $90 \mathrm{~kg} \mathrm{~N} \mathrm{ha}^{-1}$ in 1993, 1994, and 1995, respectively. Thus, the range of $\mathrm{N}$ derived from pigeon peas varied from 23 to $38 \%$ and only 6 to $10 \%$ for the fallow treatment fertilized with $90 \mathrm{~kg} \mathrm{~N}^{-1}$. Mineralization of legume $\mathrm{N}$ over an extended period, in contrast to the soluble source of fertilizer $\mathrm{N}$ may account for greater apparent recovery of $\mathrm{N}$ added with the legume source.

\section{CONCLUSIONS}

Even though legume productivity was not favorably enhanced with the use of pigeon pea specific Bradyrhizobium, the Georgia-1 pigeon pea was more productive than ICPL-87 and in a few cases, wheat biomass among the legume treatments was affected by the choice of inoculum treatment. Substitution of pigeon pea for summer fallow and chemical $\mathrm{N}$ fertilizer enhanced the productivity of winter wheat, especially the last year of the rotation. The favorable response of wheat following pigeon peas warrants development of field research into summer legume and winter wheat rotations for the southern Great Plains.

\section{ACKNOWLEDGMENTS}

This project was funded by the USDA National Research Initiative Competitive Grants Program (Grant No. 93-37311-9580), Oklahoma Wheat 
Commission, University of Central Oklahoma (UCO) Office of Sponsored Research and Grants, and the USDA-ARS Grazinglands Research Laboratory. Authors thank members of the UCO Plant Physiology Research Group for assisting with the project.

\section{REFERENCES}

1. Saxena, N.P. Screening for Adaptation to Drought: Case Studies with Chickpea and Pigeonpea. ICRISAT (International Crops Research Institute for the Semi-Arid Tropics). Adaptation of Chickpea and Pigeonpea to Abiotic Stress; Proceedings Consultants' Workshop, Dec 19-21, 1984, Patancheru, A.P.: India, 1987; 63-76.

2. Singh, L. Production Aspects of Pigeonpea and Future Prospects. ICRISAT (International Crops Research Institute for the Semi-Arid Tropics). Uses of Tropical Grain Legumes; Proceedings Consultants Meeting, March 27-30, 1989, Patancheru, A.P.: India, 1991; 121-127.

3. Whiteman, P.C.; Norton, B.W. Alternative Uses for Pigeonpea. ICRISAT (International Crops Research Institute for the Semi-Arid Tropics); Proceedings of International Workshop on Pigeonpeas, Dec 15-19, 1980, Patancheru, A.P.: India, 1981; Vol. 1, 365-377.

4. Nene, Y.L.; Sheila, V.K. Pigeonpea: Geography and Importance. In The Pigeonpea; Nene, Y.L., Hall, S.D., Sheila, V.K., Eds.; CAB International: Tucson, AZ, 1990; 1-14.

5. Kumar Rao, J.V.D.K. Pigeonpea: Nitrogen Fixation. In The Pigeonpea; Nene, Y.L., Hall, S.D., Sheila, V.K., Eds.; CAB International: Tucson, AZ, 1990; 233-256.

6. Kumar Rao, J.V.D.K.; Thompson, J.A.; Sastry, P.V.S.S.; Giller, K.E.; Day, J.M. Measurement of $\mathrm{N}_{2}$-Fixation in Field-Grown Pigeonpea (Cajanus cajan (L.) Millsp.) Using ${ }^{15} \mathrm{~N}-$ Labelled Fertilizer. Plant Soil 1987, 101 (1), 107-113.

7. Kumar Rao, J.V.D.K.; Dart, P.J.; Sastry, P.V.S.S. Residual Effect of Pigeon Pea (Cajanus cajan) on Yield and Nitrogen Response of Maize. Expl. Agric. 1983, 19 (2), 131-141.

8. Lopez, F.B.; Johansen, C.; Chauhan, Y.S. Limitations to Seed Yield in Short-Duration Pigeonpea Under Water Stress. Field Crops Res. 1994, 36 (2), 95-102.

9. Chauhan, Y.S.; Johansen, C.; Saxena, K.B. Physiological Basis of Yield Variations in Short-Duration Pigeonpea Grown in Different Environments of the Semi-Arid Tropics. J. Agron. Crop Sci. 1995, 174 (3), 163-171.

10. Quilt, P.; Dalal, R.C. Effect of Soil Mineral N Levels and Inoculation on Nodulation, Nitrogenase Activity, and Grain Yield of Pigeon Pea. Agron. J. 1979, 71 (3), 450-452. 
11. La Favre, J.S.; Focht, D.D. Comparison of $\mathrm{N}_{2}$ Fixation and Yields in Cajanus cajan Between Hydrogenase-Positive and Hydrogenase-Negative Rhizobia by in situ Acetylene Reduction Assays and Direct ${ }^{15} \mathrm{~N}$ Partitioning. Plant Physiol. 1983, 72 (4), 971-977.

12. Reference to a Trade or Company Name Is for Specific Information Only and Does Not Imply Approval or Recommendation of the Company by the USDA or University of Central Oklahoma to the Exclusion of Others That may Be Suitable.

13. Bremner, J.M.; Keeney, D.R. Determination and Isotope-Ratio Analysis of Different Forms of Nitrogen in Soils. III. Exchangeable Ammonium, Nitrate, and Nitrite by Extraction-Distillation Methods. Soil Sci. Soc. Am. Proc. 1966, 30, 577-582.

14. SAS, SAS User's Guide: Statistics, 5th Ed.; SAS Institute: Cary, NC, 1985; 1290.

15. Bidlack, J.E.; Rao, S.C.; Demezas, D.H. Nodulation, Nitrogenase Activity, and Dry Weight of Chickpea and Pigeon Pea Cultivars Using Different Bradyrhizobium Strains. J. Plant Nutr. 2001, 24 (3) in press.

16. Thompson, J.A.; Kumar Rao, J.D.V.K.; Dart, P.J. Measurement of Inoculation Response in Pigeonpea. ICRISAT (International Crops Research Institute for the Semi-Arid Tropics); Proceedings of International Workshop on Pigeonpeas, Dec 15-19, 1980, Patancheru, A.P.: India, 1981; Vol. 1, 249-253.

17. Reddy, L.J. Pigeonpea: Morphology. In The Pigeonpea; Nene, Y.L., Hall, S.D., Sheila, V.K., Eds.; CAB International: Tucson, AZ, 1990; 47-87.

18. Badaruddin, M.; Meyer, D.W. Grain Legume Effects on Soil Nitrogen, Grain Yield, and Nitrogen Nutrition of Wheat. Crop Sci. 1994, 34, 1304-1309. 